\title{
Abbreviations and Acronyms: The Case of Tlhalosi ya Medi ya Setswana
}

Joyce T. Mathangwane, Department of English, Faculty of Humanities, University of Botswana, Gaborone, Botswana (mathanjt@mopipi.ub.bw)

\begin{abstract}
This paper looks at how abbreviations and acronyms are treated in African language dictionaries in general compared to selected mainstream English dictionaries. Specifically, the study looks at their treatment in T.J. Otlogetswe's (2012) Tlhalosi ya Medi ya Setswana dictionary. Altogether, a survey of twenty selected dictionaries was carried out examining the treatment of abbreviations and acronyms in these dictionaries. Ten of these dictionaries are mainstream English dictionaries and the remaining ten are dictionaries of varied African languages spoken in the Southern African region e.g. Shona, Ndebele, Venda, Setswana and Northern Sotho. The study addresses four questions: (a) whether African lexicographers include abbreviations and acronyms in their dictionaries as is practice in mainstream English dictionaries; (b) if so, how these have been treated; (c) what linguistic features are highlighted in these entries, if any; and, (d) what recommendation the study makes for the way forward.

The results showed that in most of the African dictionaries in the survey, unlike in mainstream English dictionaries, abbreviations and acronyms are not included despite the fact that many of them are coined and used by native speakers of these languages. An exception is Otlogetswe (2012) with a list of 25 abbreviations and acronyms. The paper recommends that African lexicographers include abbreviations and acronyms as part of their lexicon because these lexical items are coined by the communities making them part of the vocabulary of the language. Users of these dictionaries should find entries of abbreviations and acronyms in these dictionaries whenever they want to confirm the meaning, or when teaching.
\end{abstract}

Keywords: ABBREVIATIONS, ACRONYMS, AFRICAN LANGUAGES, DICTIONARY, FRENCH ACRONYMS, LEMMAS, LEXICOGRAPHERS, MONOLINGUAL, PRONUNCIATION, SEMANTIC PROPERTIES, STRESS, TONE

Opsomming: Afkortings en akronieme: Die voorbeeld van Tlhalosi ya Medi ya Setswana. Hierdie artikel kyk na hoe afkortings en akronieme oor die algemeen hanteer word in Afrikataalwoordeboeke in vergelyking met verkose hoofstroom Engelse woordeboeke. Spesifiek word gekyk na die hantering daarvan in T.J. Otlogetswe (2012) se woordeboek Tlhalosi ya Medi ya Setswana. 'n Ondersoek na die hantering van afkortings en akronieme in altesaam twintig verkose woordeboeke is uitgevoer. Tien van hierdie woordeboeke is hoofstroom Engelse woordeboeke en die res is woordeboeke van verskillende Afrikatale wat in Suider-Afrika gepraat word, bv. Shona, Ndebele, Venda, Setswana en Noord-Sotho. Die studie spreek vier kwessies aan: (a) of Afrikataalleksikograwe afkortings en akronieme in hul woordeboeke insluit soos wat by hoofstroom Engelse woordeboeke die gebruik is; (b) indien wel, hoe hulle hanteer is; (c) watter linguis-

Lexikos 25 (AFRILEX-reeks/series 25: 2015): 233-245 
tiese kenmerke, indien enige, in hierdie inskrywings beklemtoon word; en, (d) watter aanbevelings hierdie studie vir die pad vorentoe maak.

Die resultate het getoon dat afkortings en akronieme in die meeste Afrikataalwoordeboeke in die ondersoek, anders as in hoofstroom Engelse woordeboeke, nie opgeneem is nie, alhoewel baie van hulle deur moedertaalsprekers van hierdie tale geskep is en gebruik word. ' $n$ Uitsondering is Otlogetswe (2012) met 'n lys van 25 afkortings en akronieme. In hierdie artikel word aanbeveel dat Afrikataalleksikograwe afkortings en akronieme as deel van hul leksikon insluit, aangesien hierdie leksikale items geskep is deur gemeenskappe wat hulle deel maak van die woordeskat van die taal. Gebruikers van hierdie woordeboeke behoort inskrywings van afkortings en akronieme in dié woordeboeke te vind wanneer hulle die betekenis daarvan naslaan of hulle tydens onderrig raadpleeg.

Sleutelwoorde: AFKORTINGS, AKRONIEME, AFRIKATALE, WOORDEBOEK, FRANSE AKRONIEME, LEMMAS, LEKSIKOGRAWE, EENTALIG, UITSPRAAK, SEMANTIESE EIENSKAPPE, KLEM, TOON

\section{Introduction}

According to Cannon (1989), the use of abbreviations and acronyms go back several millennia and was driven by the desire to economise. However, the real explosion of 'initialisms' (as they are referred to in his study) began with World War II when American English introduced so many of these initialisms, some of which were ridiculously absurd and long, e.g. USAMSMADHS 'United States Army Medical Service Meat and Dairy Hygiene School' (Cannon 1989: 101). Cannon notes that "Over the centuries, the purpose of creating these initialisms also has changed from the original medieval need for economy and efficiency ..." According to Hamilton 1918 (cited in Cannon 1989: 103) "The use of abbreviations and signs is often a convenience and sometimes a temptation. ... a saving of time and labour which is entirely justifiable under certain conditions." As a result, so many dictionaries of acronyms have been written on different areas of specialised vocabulary. This paper predicts another boom in the creation of new abbreviations and acronyms because of new technologies such as mobile phones and the increasing use of SMSs (Short Message Service), WhatsApp and other social media such as Facebook and Twitter. Already, the Oxford Dictionary and Thesaurus lists verbs derived from the noun SMS, as SMSs (third person singular verb), SMSing (progressive aspect) and SMSed (past tense) (Waite 2007: 980).

The purpose of this paper is to look at how abbreviations and acronyms are treated in dictionaries in general. Specifically, the study looks at how abbreviations and acronyms are treated in T.J. Otlogetswe's Thalosi ya Medi ya Setswana which was published in 2012. Otlogetswe's (2012) treatment of abbreviations and acronyms is compared to that of selected English dictionaries and other African languages in the Southern African region. This study carried out a comparative survey of twenty dictionaries, ten English diction- 
aries and ten dictionaries of African languages, to outline the differences between these two sets of dictionaries in terms of their treatment of acronyms and abbreviations. Several questions are addressed in this study: (a) do African lexicographers include abbreviations and acronyms in their dictionaries as seems to be practice in mainstream English dictionaries; (b) if so, how have these been treated in these dictionaries; (c) what linguistic features are highlighted in these entries; and, (d) what recommendation does the study make regarding the inclusion of these forms in African dictionaries as a way forward?

\section{Definitions of abbreviations and acronyms}

According to the Concise Oxford Companion to the English Language edited by McArthur (1998: 1, 8), an abbreviation is the "shortening of words and phrases ..." whereas an acronym "is an abbreviation from the first letters of a series of words and pronounced as one word". His definition makes a distinction between the two in that the former is pronounced as letters of the alphabet while the latter is pronounced as one word e.g. ATM (Automated Teller Machine) and WAR (Women Against Rape) respectively.

Yule (1996: 68) refines the definition of acronyms a little further and writes:

acronyms, are formed from the initial letters of a set of words. These can remain essentially 'alphabetisms' such as $C D$ ('compact disk') ... where the pronunciation consists of a set of letters. More typically, acronyms are pronounced as single words, as in NATO, NASA or UNESCO.

Landau (1989: 27), on the other hand, attempts to make a clear distinction between abbreviations and acronyms when he states:

An abbreviation is a shortened form for a word or phrase, consisting of the word or the first letter of each of the words in the phrase, or sometimes the first two letters.

An acronym is a form of abbreviation composed of the first or the first two letters, or a syllable from each of the words in a compound term or phrase, so ordered that the resulting series of letters is usually pronounced as a word.

Landau (1989: 27) further notes that sometimes the distinction between abbreviations and acronyms is arbitrary as speakers often pronounce and treat them as one, in that what one considers an acronym, others may choose to spell out the individual letters, thus making it an abbreviation or alphabetism as well. He cites the acronym AWOL (absent without leave), which some speakers pronounce as a word, making it an acronym, while others pronounce it as a sequence of letters, in which case it is an abbreviation. In this paper though, we adopt Landau (1989)'s definition of the two terms, abbreviation and acronym. The terms alphabetisms or initialisms will not be used. 


\section{The treatment of acronyms in selected dictionaries}

\section{English Dictionaries}

Altogether, ten selected English dictionaries were surveyed looking at whether abbreviations and acronyms are included in these dictionaries and, if so, how are they represented. The following table gives the results of the survey:

Table 1: Abbreviations and acronyms in selected English dictionaries

\begin{tabular}{|c|c|c|c|}
\hline Dictionary & $\begin{array}{l}\text { Year of } \\
\text { Publication }\end{array}$ & Classification & $\begin{array}{l}\text { Acronyms/ Abbre- } \\
\text { viations }\end{array}$ \\
\hline $\begin{array}{l}\text { The New American Webster } \\
\text { Handy College Dictionary. } \\
\text { Morehead, Albert and Loy } \\
\text { Morehead (Eds.). } \\
\text { (NAWHCD) }\end{array}$ & 1981 & Monolingual & $\begin{array}{l}\text { Yes, a list of abbre- } \\
\text { viations and acro- } \\
\text { nyms is given sepa- } \\
\text { rately as a back mat- } \\
\text { ter text }\end{array}$ \\
\hline $\begin{array}{l}\text { The Concise Oxford Dictionary } \\
\text { of Current English. Sykes, J.B. } \\
\text { (Ed.). (CODCE) }\end{array}$ & 1982 & Monolingual & $\begin{array}{l}\text { Yes, listed as part of } \\
\text { the lexicon/lemma- } \\
\text { tised in the macro- } \\
\text { structure }\end{array}$ \\
\hline $\begin{array}{l}\text { Collins Concise Dictionary } \\
\text { (4th Edition). (CCD) }\end{array}$ & 1999 & Monolingual & $\begin{array}{l}\text { Yes, listed as part of } \\
\text { the lexicon/lemma- } \\
\text { tised in the macro- } \\
\text { structure }\end{array}$ \\
\hline $\begin{array}{l}\text { Longman Dictionary of Con- } \\
\text { temporary English. New Edi- } \\
\text { tion. (LDCE) }\end{array}$ & 1987 & Monolingual & $\begin{array}{l}\text { Yes, as part of the } \\
\text { lexicon/lemmatised } \\
\text { in the macrostruc- } \\
\text { ture }\end{array}$ \\
\hline $\begin{array}{l}\text { Longman Dictionary of Eng- } \\
\text { lish Language and Culture. } \\
\text { (LDELC) }\end{array}$ & 1998 & Monolingual & $\begin{array}{l}\text { Yes, listed as part of } \\
\text { the lexicon/lemma- } \\
\text { tised in the macro- } \\
\text { structure }\end{array}$ \\
\hline $\begin{array}{l}\text { Oxford Advanced Learner's } \\
\text { Dictionary of Current English. } \\
\text { Hornby, A.S. (7th Edition). } \\
\text { Wehmeier, Sally (Chief ed.). } \\
\text { (OALDCE) }\end{array}$ & 2005 & Monolingual & $\begin{array}{l}\text { Yes, as part of the } \\
\text { lexicon/lemmatised } \\
\text { in the macrostruc- } \\
\text { ture }\end{array}$ \\
\hline $\begin{array}{l}\text { Cambridge International Dic- } \\
\text { tionary of English. (CIDE) }\end{array}$ & 1996 & Monolingual & $\begin{array}{l}\text { Yes, listed as part of } \\
\text { the lexicon/lemma- } \\
\text { tised in the macro- } \\
\text { structure }\end{array}$ \\
\hline
\end{tabular}




\begin{tabular}{|l|l|l|l|}
\hline $\begin{array}{l}\text { Longman Dictionary of Lan- } \\
\text { guage Teaching and Applied } \\
\text { Linguistics. Richards, Jack C. } \\
\text { and Heidi Platt. (LDLTAL) }\end{array}$ & 1999 & Monolingual & $\begin{array}{l}\text { Yes, a limited list of } \\
\text { specialised acro- } \\
\text { nyms and abbrevia- } \\
\text { tions/lemmatised } \\
\text { in the macrostruc- } \\
\text { ture }\end{array}$ \\
\hline $\begin{array}{l}\text { Macmillan English Dictionary } \\
\text { for Advanced Learners. Inter- } \\
\text { national Student Edition. } \\
\text { (MEDAL) }\end{array}$ & 2002 & Monolingual & $\begin{array}{l}\text { Yes, as part of the } \\
\text { lexicon/lemmatised } \\
\text { in the macrostruc- } \\
\text { ture }\end{array}$ \\
\hline $\begin{array}{l}\text { Oxford Dictionary and Thesau- } \\
\text { rus. Waite, Maurice (Ed.). } \\
\text { (ODT) }\end{array}$ & 2007 & Monolingual & $\begin{array}{l}\text { Yes, listed as part of } \\
\text { the lexicon/lemma- } \\
\text { tised in the macro- } \\
\text { structure }\end{array}$ \\
\hline
\end{tabular}

Nine of the ten English dictionaries lemmatise abbreviations and acronyms in the macrostructure as part of the vocabulary while one includes them in a list as a back matter text.

In seven of the above dictionaries, an interesting observation can be made regarding the phonological representation of these abbreviations and acronyms in the lexicon. In six of these dictionaries, the pronunciation of the acronyms and abbreviations is given using IPA symbols (International Phonetic Alphabet), and these transcriptions are also marked for stress. Acronyms, which are pronounced as the spelling suggests, are marked for primary stress only, which is the strongest type, while abbreviations carry both primary stress represented with a high mark ['] and secondary stress (less prominent) represented with a low mark []], as illustrated below:

\section{Abbreviations:}

FBI abbrev. /,efbi:'aI / ... for the Federal Bureau of Investigation; the police department in the US which is controlled by the national government and which deals with serious crimes that involve people or places in more than one of the states in the US ... (LDELC, p. 472)

PX /,pi:'eks/ ...abbreviation for post exchange ... (LDELC, p. 1089)

BA /,bi:'ei/ ... abbreviation for Bachelor of Arts .... (CIDE, p. 88)

UAE / ju:er'i:/ ... abbreviation for United Arab Emirates (CIDE, p. 1577)

CBS /,si:bi:'es / abbr (in the USA) Columbia Broadcasting System: a CBS news broadcast: to CBS (OALDCE, p. 235) 


\section{Acronyms:}

UNICEF /'ju:nısef/ n ... abbreviation for United Nations International Children's Fund (CIDE, p. 1589)

ACAS /'erkæs/ abbr (in Britain) Advisory, Conciliation and Arbitration Service (an organization that helps with negotiation during industrial disputes) (OALDCE, p. 7)

NASA /'næsə/ (in the USA) National Aeronautics and Space Administration (OALDCE, p. 1013)

UNESCO /ju:'neskəv/ abbr United Nations Educational, Scientific and Cultural Organization (OALDCE, p. 1670)

OPEC /'oupek/n [the] Organization of Petroleum Exporting Countries; a group of countries that produce oil and plan together how to sell it ... (OALDCE, p. 1062)

Abbreviations, on the one hand, are considered complex 'words', hence they are marked for both primary and secondary stress. It seems that acronyms, on the other hand, are phonologically considered to be simple 'words' and carry tonic or primary stress. Both monosyllabic and disyllabic acronyms carry primary stress on the first syllable while polysyllabic ones can carry stress either on the first or second syllable as indicated above.

However, some exceptions to the above treatment include The New American Webster Handy College Dictionary (Albert and Loy Morehead 1981), the Oxford Dictionary and Thesaurus (Waite 2007), and the Concise Oxford Dictionary of Current English (Sykes 1982). The New American Webster Handy College Dictionary (1981) provides a separate list of abbreviations and acronyms at the end of the dictionary as a back text, while the latter two indicate the pronunciation of acronyms by way of orthographic rewriting, and none at all for abbreviations.

\section{Dictionaries of African Languages}

A survey of dictionaries of some African languages in the Southern African region was also carried out to establish how African lexicographers have dealt with abbreviations or acronyms in their respective languages. This list, though by no means exhaustive, indicates that many of these dictionaries do not include abbreviations or acronyms in their lexicon, even those that are coined and commonly used by speakers of the respective languages. Table two below provides the results of a survey of a selection of dictionaries. 
Table 2: Abbreviations and acronyms in a selection of dictionaries on African languages in Southern Africa

\begin{tabular}{|c|c|c|c|}
\hline Dictionary & $\begin{array}{l}\text { Year of } \\
\text { Publication }\end{array}$ & $\begin{array}{l}\text { Classification and } \\
\text { Language(s) }\end{array}$ & $\begin{array}{l}\text { Acronyms/ Abbre- } \\
\text { viations }\end{array}$ \\
\hline $\begin{array}{l}\text { Kgasa, M.L.A. Thanodi ya } \\
\text { Setswana ya Dikole. }\end{array}$ & 1976 & $\begin{array}{l}\text { Monolingual } \\
\text { Setswana }\end{array}$ & None \\
\hline $\begin{array}{l}\text { Van Warmelo, N.J. } \\
\text { Venda Dictionary: } \\
\text { Tshivenda-English. }\end{array}$ & 1989 & $\begin{array}{l}\text { Bilingual } \\
\text { Tshivenda and } \\
\text { English }\end{array}$ & None \\
\hline $\begin{array}{l}\text { Matumo, Z.I. (Compiler). } \\
\text { Setswana-English- } \\
\text { Setswana Dictionary. }\end{array}$ & 1993 & $\begin{array}{l}\text { Bilingual } \\
\text { Setswana and } \\
\text { English }\end{array}$ & None \\
\hline $\begin{array}{l}\text { Kgasa, M.L.A. and } \\
\text { J. Tsonope Thanodi ya } \\
\text { Setswana. }\end{array}$ & 1995 & $\begin{array}{l}\text { Monolingual } \\
\text { Setswana }\end{array}$ & None \\
\hline $\begin{array}{l}\text { Chimhundu, } \mathrm{H} \text {. } \\
\text { Duramazwi reChiShona. }\end{array}$ & 1996 & $\begin{array}{l}\text { Monolingual } \\
\text { Shona }\end{array}$ & None \\
\hline $\begin{array}{l}\text { Otlogetswe, T.J. English- } \\
\text { Setswana Dictionary. }\end{array}$ & 2007 & $\begin{array}{l}\text { Bilingual } \\
\text { English and } \\
\text { Setswana }\end{array}$ & $\begin{array}{l}2 \\
\text { (HIV and Aids) }\end{array}$ \\
\hline $\begin{array}{l}\text { De Schryver, G.-M. (Ed.). } \\
\text { English-Northern Sotho. } \\
\text { Oxford Bilingual School } \\
\text { Dictionary. }\end{array}$ & 2007 & $\begin{array}{l}\text { Bilingual } \\
\text { English and Northern } \\
\text { Sotho }\end{array}$ & $\begin{array}{l}3 \text { in the Northern } \\
\text { Sotho side and } 6 \text { in } \\
\text { the English side } \\
\text { (HIV and Aids } \\
\text { included) }\end{array}$ \\
\hline $\begin{array}{l}\text { Mojela, V. (Ed.). } \\
\text { Pukuntšutlhaloši ya } \\
\text { Sesotho sa Leboa. }\end{array}$ & 2007 & $\begin{array}{l}\text { Monolingual } \\
\text { Sesotho as Leboa }\end{array}$ & $\begin{array}{l}2 \\
\text { (HIV and Aids) }\end{array}$ \\
\hline $\begin{array}{l}\text { Hadebe, S. Isichazamazwi } \\
\text { SesiNdebele. }\end{array}$ & 2001 & $\begin{array}{l}\text { Monolingual } \\
\text { Ndebele }\end{array}$ & None \\
\hline $\begin{array}{l}\text { Otlogetswe, T.J. Tlhalosi } \\
\text { ya Medi ya Setswana. }\end{array}$ & 2012 & $\begin{array}{l}\text { Monolingual } \\
\text { Setswana }\end{array}$ & $\begin{array}{l}25 \text { abbreviations } \\
\text { and acronyms }\end{array}$ \\
\hline
\end{tabular}

From the above table, it is obvious that African lexicographers in general have not been paying much attention to abbreviations or acronyms when producing dictionaries in their respective languages. Of the ten dictionaries surveyed, including languages such as Setswana, IsiNdebele, ChiShona, Northern Sotho or Sesotho sa Leboa, Otlogetswe (2012) is the only one with larger list of abbreviations and acronyms in his lexicon of Setswana, altogether 25 are listed. This omission is even more noticeable in older dictionaries dating as far back as the 1980s or 1990s, for example, Setswana English Setswana Dictionary (Matumo 1993) 
on Setswana and English, and Venda Dictionary: Tshivenda-English (Van Warmelo 1989) on Tshivenda. The only acronyms which are slowly making their way into some of the more current dictionaries are HIV and Aids which appears in four of the above dictionaries. These four are, Pukuntšutlhaloši ya Sesotho sa Leboa (Mojela 2007); English-Northern Sotho Oxford Bilingual School Dictionary (De Schryver 2007); English-Setswana Dictionary (Otlogetswe 2007) and Tlhalosi ya Medi ya Setswana (Otlogetswe 2012). It is interesting to note that Shona has a word for HIV/AIDS, mukonombera. Hence, there was no need to include the entry HIV/AIDS in the dictionary. With the exception of Thalosi ya Medi ya Setswana (Otlogetswe 2012), most of the selected dictionaries on African languages surveyed have a very brief list of abbreviations and acronyms in their lexicon ranging from zero (e.g. Kgasa 1976; Van Warmelo 1989; Matumo 1993) to nine (as in De Schryver 2007).

\section{Abbreviations and acronyms in Tlhalosi ya Medi ya Setswana by T.J. Otlogetswe}

As already noted above, Tlhalosi ya Medi ya Setswana (Otlogetswe 2012), which is a more recent dictionary, includes a short list of 14 abbreviations and 11 acronyms commonly used in the Setswana language. The list is reproduced below in its entirety.

Table 3: List of abbreviations and acronyms in Thalosi ya Medi ya Setswana, adapted from Otlogetswe (2012)

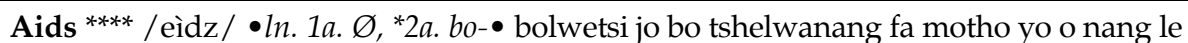
jone a thakanela dikobo le yo mongwe ba sa itshireletsa, kgotsa ka go arogana dieledi tsa mmele le molwetsi wa jone; bo bolayang masole a mmele mme bo paledise mmele go itshireletsa kgatlhanong le malwetsi Acquired Immune Deficiency Syndrome = SEGAJAJA

BCP / bì:sì:pì/ •ln. 1a. Ø, *2a. bo-• nngwe ya diphathi tsa sepolotiki tsa Botswana Botswana Congress Party

BDP / bì:dì:pì:/ •ln. 1a. Ø, *2a. bo-• nngwe ya diphathi tsa sepolotiki tsa Botswana Botswana Democratic Party

BIDPA /bídpà / •ln. 1a. Ø, *2a. bo-• lekalana le le ikemetseng ka nosi la Botswana le le itebagantseng le go sekaseka mananeo le go netefatsa gore a dirisiwa ka fa go tshwanetseng Botswana Instituition of Development and Planning Analysis

BMD /bì:emdì:/ •ln. 1a. Ø, *2a. bo-• nngwe ya diphathi tsa sepolotiki tsa Botswana Botswana Movement for Democracy

BNF *** /bì:enef/ •ln. 1a. Ø, *2a. bo-• nngwe ya diphathi tsa sepolotiki tsa Botswana Botswana National Front

BONEPWA / bùnèpwá/ •ln. 1a. $\varnothing,{ }^{*} 2 a$. bo-• lekalana le le ikemetseng ka nosi mo Botswana le le thusang batho ba ba tshelang ka mogare wa HIV/Aids ka go ba fa dikgakololo tse ba di tlhokang Botswana Network of People Living with HIV and AIDS
} 
BOTUSA / bùtúsà / •ln. 1a. Ø, *2a. bo-• kgokagano ya puso ya Botswana le lekalana la twantsho le taolo ya malwetsi la Amerika le le lwantshang malwetsi a tshwana le kgotlholo e kgolo le HIV / AIDS Botswana USA

BPC /bì:pì:sì:/ •ln. 1a. Ø, *2a. bo-• kompone e e anamisang motlakase mo lefatsheng la Botswana Botswana Power Corporation

BPP /bì:pì:pì:/ •ln. 1a. Ø, *2a. bo-• nngwe ya diphathi tsa sepolotiki tsa Botswana Botswana People's Party = MAGATAMMÔGÔ

BSB / bì:esbì:/ •ln. 1a. Ø, *2a. bo-• banka ya poloko-madi ya Botswana Botswana Savings Bank

BSE / bì:es ì:/ •ln. 1a. Ø, *2a. bo-• lekgotla le le rekisang diabe la Botswana Botswana Stock Exchange

BTA **** /bì:tì:eì/ •ln. 1a. Ø, *2a. bo-• lekgotla le le okametseng tsa ditlhaeletsanyo la Botswana Botswana Telecommunications Authority

BTC /bì:tì:sì:/ •ln. 1a. Ø, *2a. bo-• kompone e e okametseng ditlhaeletsano tsa megala mo Botswana Botswana Telecommunications Corporation

BTU /bì:tì:jù:/ •ln. 1a. Ø, *2a. bo-• lekgotla la barutabana ba Botswana Botswana Teachers Union

Btv / bì:tì:vì:/ •ln. 1a. Ø, *2a. bo-• thelebišene ya setšhaba ya lefatshe la Botswana Botswana Television

COSAFA / khòsáfà / •ln. 1a. Ø, *2a. bo-• lekgotla le le okametseng kgwele ya dinao mo borwa jwa Aforika Confederation of Southern African Football Association

COSATU / k h̀̀átù/ •ln. 1a. Ø, *2a. bo-• mokgatlho o o okametseng mekgatlho ya badiri ba Aforika Borwa Congress of South African Trade Unions

FIFA / fífà / •ln. 1a. Ø, *2a. bo-• mokgatlho o o tsamaisang motshameko wa kgwele ya dinao mo lefatsheng ka bophara Fédération Internationale de Football Association

NDP /endì:pì:/ •ln. 1a. Ø, *2a. bo-• lenaneo la ditlhabololo tsa setšhaba National Development Plan

UCCSA /jù:sì:sì:eseì / •ln. 1a. Ø, *2a. bo-• kereke ya Lontone e e mo mafatsheng a borwa jwa Aforika United Congregational Church of Southern Africa

UNESCO /jùnìskhù / •ln. 1a. $\varnothing, * 2 a$. bo-• lekgotlana la mafatshe a a kopaneng le le dirang le thuto,tsa boranyane le ngwao United Nations Educational Scientific and Cultural Organisation

UNIBO /jùníbù/ •ln. 1a. Ø, *2a. bo-• leina la yunibesithi ya Aforika Borwa e e neng e le mo kgaolong ya Bophuthatswana University of Bophuthatswana

UNICEF /jùnìsèf/ •ln. 1a. Ø, *2a. bo-• lekgotlana la mafatshe a a kopaneng le le inaakantseng le go sireletsa bana lefatshe ka bophara United Nations Childrens Fund WABO /wàbù / •In. 1a. Ø, *2a. bo-• mokgatlho wa bakwadi mo Botswana Writers Association of Botswana

All these twenty-five abbreviations and acronyms are also lemmatised in the dictionary in alphabetical order together with all the other lexical items. And, just like all the other lexical entries in the dictionary, the following information is provided for each: 
(a) Stars or asterisks $\left(^{(* * *)}\right.$ to indicate how frequent the lexical item (word) is used in Setswana, e.g. Aids, which is followed by four asterisks $(* * *)$, indicating that it is one of the 1000 words most frequently used in Setswana

(b) Pronunciation of the abbreviation or acronym using IPA e.g. /eidz/ (Aids)

(c) Tone marks on the transcription indicating whether High or Low tones are used, using the appropriate diacritic marks e.g. UNIBO /jùníbù /

(d) An indication of whether or not the lexical item is a name by way of the abbreviation $\ln$ (leina - 'name')

(e) Noun Class of the entry followed by its class prefix, e.g. Aids $=$ class 1a. $\varnothing$ (zero prefix)

(f) Class prefix for the plural form of the lexical item and its prefix e.g. Aids $={ }^{*} 2 \mathrm{a}$. bo-

(g) Explanation/meaning of the entry in Setswana

(h) The actual name represented by the abbreviation or acronym in English, e.g. Aids = Acquired Immune Deficiency Syndrome, or any other language, such as French

(i) The last information given for this entry is the Setswana name for Aids i.e. SEGAJAJA.

(Tlhalosi ya Medi ya Setswana (Otlogetswe 2012))

The above data entries ( $\mathrm{a}-\mathrm{h}$ ) cover the phonology, morpho-syntactic and semantic aspects of each lexical item. This data is provided for all the other lexical items in the dictionary, abbreviations and acronyms included, an indication that these are equal lexical items in the language even if borrowed from a foreign language. This is illustrated well by a word such as FIFA, which is derived from French. The acronym FIFA is derived from the French Fédération Internationale de Football Association. However, this acronym is widely used as is in many languages across the globe. The word FIFA is treated as follows in this dictionary:

FIFA / fífà / •ln. 1a. Ø, *2a. bo-• mokgatlho o o tsamaisang motshameko wa kgwele ya dinao mo lefatsheng ka bophara Fédération Internationale de Football Association

(Tlhalosi ya Medi ya Setswana (Otlogetswe 2012: 104))

An example such as FIFA is an interesting one in that it also appears in many of the conventional English dictionaries and where listed, the French name from which it is derived may also be provided. For instance, the Longman Dictionary of English Language and Culture (1998: 478) writes, 
FIFA /'fi:fə/ abbrev. for Fédération Internationale de Football Association; the organization that controls international football and organizes the WORLD CUP competition.

The Macmillan English Dictionary for Advanced Learners, International Student Edition (2002: 518) also writes,

FIFA /'fi:fa/ the international organization that makes rules and decisions relating to the sport of football. FIFA is an abbreviation of the organization's name.

Another interesting example of an acronym derived from French and yet used as such in the English language is CERN listed in the 5th edition of the Oxford Advanced Learner's Dictionary of Current English (5th Edition) (1995) as follows:

CERN ... /'sz:n/ abbr European Organisation for Nuclear Research (French Conseil Européen pour la Recherche Nucléaire)

Such entries clearly indicate that acronyms may even be borrowed from another language, a fact that some users may be unaware of. The fact that they are used in any particular language of the dictionary, justifies their inclusion in the dictionary of that language as some dictionary users may consult it for acronyms.

\section{Conclusion}

From the surveyed dictionaries above, we conclude that all the English dictionaries in the survey include abbreviations and acronyms in their lemma list. They are considered part of the lexicon as they are lemmatised in alphabetical order with all the other lemmas. With the exception of Tlhalosi ya Medi ya Setswana (Otlogetswe 2012), dictionaries of African languages have tended to ignore these abbreviations and acronyms even though many of them are commonly used in the respective languages. Some of these abbreviations or acronyms are coined by the particular language communities as new organizations are formed within the country. In Botswana, for instance, new entries come into the language every time a new organisation is formed, e.g. BIUST (Botswana International University of Science and Technology); BITRI (Botswana Institute for Technology Research and Innovation); BOCRA (Botswana Communications Regulatory Authority), and many others.

This paper therefore argues for the inclusion of abbreviations and acronyms when compiling dictionaries of African languages, something which many African lexicographers have tended to overlook until recently. It is necessary that African lexicographers include these abbreviations and acronyms in their dictionaries as they form part of vocabulary of the various African languages, for which information may be sought in dictionaries. Many of these abbreviations and acronyms have high frequencies in these African languages justifying their inclusion in these dictionaries. For instance, Otlogetswe (2014)'s 
keyword analysis of the top 100 business key words from a Setswana corpus of well over a million tokens indicate high frequencies for some of these abbreviations and acronyms as follows: BTC - (Botswana Telecommunications Corporation (69); PEEPA - Public Enterprises Evaluation and Privatisation Agency (27); BOBS - Botswana Bureau of Standards (29); SACU — Southern African Customs Union (13); BOCCIM - Botswana Confederation of Commerce, Industry and Manpower (20); and, GPH - Gaborone Private Hospital (13) (Otlogetswe 2014: 280-283).

Otlogetswe (2012) not only treated abbreviations and acronyms as part of the lexicon, he provided the phonological, morpho-syntactic and semantic properties of these lemmas, as well as the actual names of the organizations that they stand for. Even though Otlogetswe's (2012) list is very limited at twenty-five entries only, it is a good start. Hopefully more entries of abbreviations and acronyms used in Botswana and elsewhere will be captured in the second edition of this dictionary, as ideally it should. Furthermore, Otlogetswe (2012) lists the borrowed acronym FIFA (Fédération Internationale de Football Association) and its French name just as some of the conventional English dictionaries such as the Oxford, Longman and Macmillan dictionaries. Even if the name of the organization is borrowed from another language, it deserves a place in the dictionary to guide the users if in fact the abbreviation or acronym is known to and used by the speakers of the particular language. This paper therefore recommends that African lexicographers should include abbreviations and acronyms in the later editions of their dictionaries to assist language learners and users to know what these forms stand for and how to use them. Also worth noting is that, some of these abbreviations and acronyms are created or coined by the communities of these languages, thus making them part of the vocabulary of these languages. The practice should be to also include forms that are part and parcel of the society's language or languages. Such practice does not, in any way, tarnish the purity of that particular language, but rather adds to the communicative value of the dictionary by giving users access to commonly used abbreviations and acronyms, their meaning, how to pronounce them, what they mean, etc.

\section{References}

\section{Dictionaries}

CIDE $=$ Procter, Paul (Ed.). 1996. Cambridge International Dictionary of English. Cambridge: Cambridge University Press.

Chimhundu, H. (Ed.). 1996. Duramazwi reChiShona. Allex Project. Harare: College Press.

CCD $=$ Collins Concise Dictionary .1999 . Fourth Edition. Glasgow: HarperCollins.

Concise Oxford Companion to the English Language. 1998 = McArthur, Tom (Ed.). 1998. Concise Oxford Companion to the English Language. Oxford: Oxford University Press.

CODCE $=$ Sykes, J.B. (Ed.). 1982. The Concise Oxford Dictionary of Current English. Oxford: Clarendon Press. 
English-Northern Sotho. Oxford Bilingual School Dictionary. 2007 = De Schryver, Gilles-Maurice (Ed.). 2007. Oxford Bilingual School Dictionary: Northern Sotho and English/Pukuntšu ya Polelopedi ya Sekolo: Sesotho sa Leboa le Seisimane. E gatišitšwe ke Oxford. Cape Town: Oxford University Press Southern Africa.

Hadebe, S. et al. (Eds.). 2001. Isichazamazwi SesiNdebele. Harare: College Press.

Kgasa, M.L.A. (Ed.). 1976. Thanodi ya Setswana ya Dikole. Cape Town: Longman Penguin Southern Africa.

Kgasa, M.L.A. and J. Tsonope. 1995. Thanodi ya Setswana. Gaborone: Longman Botswana.

LDCE $=$ Summers, D. (Ed.). 1987. Longman Dictionary of Contemporary English. New Edition. Harlow: Longman.

LDELC = Summers, D. (Ed.). 1998. Longman Dictionary of English Language and Culture. New Edition. Harlow: Longman.

LDLTAL = Richards, Jack C., John Platt and Heidi Platt (Eds.). 1999. Longman Dictionary of Language Teaching and Applied Linguistics. New Edition. Harlow: Longman.

MEDAL = Rundell, M. (Ed.). 2002. Macmillan English Dictionary for Advanced Learners. International Student Edition. Oxford: Macmillan Education.

Matumo, Z.I. (Compiler). 1993. Setswana-English-Setswana Dictionary. Gaborone: Botswana Book Centre and Macmillan Botswana Publishers.

Mojela, V. (Ed.). 2007. Pukuntšuthaloši ya Sesotho sa Leboa. Pietermaritzburg: Nutrend Publishers.

NAWHCD = Morehead, Albert and Loy Morehead (Eds.). 1981. The New American Webster Handy College Dictionary. New York: Penguin Group.

Otlogetswe, T.J. 2007. English-Setswana Dictionary. Gaborone: Pentagon Publishers.

Otlogetswe, T.J. 2012. Thalosi ya Medi ya Setswana. Gaborone: Medi Publishing.

Oxford Advanced Learner's Dictionary of Current English. 1995 = Hornby, A.S. 1995. Oxford Advanced Learner's Dictionary of Current English. Fifth Edition. Oxford: Oxford University Press.

OALDCE $=$ Hornby, A.S. 2005. Oxford Advanced Learner's Dictionary of Current English. Seventh Edition. Chief Editor Sally Wehmeier. Oxford: Oxford University Press.

Van Warmelo, N.J. 1989. Venda Dictionary: Tshivenda-English. Pretoria: J.L. van Schaik.

ODT = Waite, Maurice (Ed.). 2007. Oxford Dictionary and Thesaurus. Oxford: Oxford University Press.

\section{Other literature}

Cannon, G. 1989. Abbreviations and Acronyms in English Word-formation. American Speech 64(2): 99-127.

Landau, S.I. 1989. Dictionaries: The Art and Craft of Lexicography. Cambridge: Cambridge University Press.

Otlogetswe, T.J. 2014. Corpus Linguistics Method: A Case of Extracting Business Terms for Dictionary Subject Label. Khumalo, Langa (Ed.). 2014. African Languages and Linguistic Theory: A Festschrift in Honour of Professor Herbert Chimhundu. Cape Town: The Centre for Advanced Studies of African Society (CASAS).

Yule, G. 1996. The Study of Language. Second Edition. Cambridge: Cambridge University Press. 